\title{
ASPECTOS PROCESSUAIS DO CONTROLE ABSTRATO DA CONSTITUCIONALIDADE NO BRASIL
}

\section{GUSTAVO BINENBOJM*}

I. O sistema eclético de controle da constitucionalidade adotado no Brasil: origens históricas e desenvolvimento. O Projeto de Lei $n^{2} 2.960 / 97$. - II. A ação direta de inconstitucionalidade contra atos comissivos: II.I. natureza jurídica do processo: processo objetivo, sem contraditório (controvérsias); 1I.1.1. indisponibilidade da ação (vedação à desistência); II.1.2. hipóteses restritas de parcialidade dos julgadores; II.1.3. inexistência de fase instrutória (controvérsias); II.2. partes: II.2.1 pertinência temática; II.2.2. capacidade postulatória dos entes legitimados; II.2.3. confederaçāo sindical e entidade de classe de âmbito nacional; II.2.4. litisconsórcio e assistência; II.2.5. a figura do amicus curiae; II.2.6. o papel do Advogado-Geral da União; II.2.7. a posição do Chefe do Poder Executivo nos casos de sanção e veto; 1I.3. objeto: II.3.1. o significado da expressão "lei ou ato normativo"; 11.3.2. atos normativos de 20 grau; II.3.3. atos normativos municipais; II.3.4. atos normativos distritais; II.3.5. atos normativos anteriores à Constituição; II.3.6. atos normativos revogados antes ou no curso do procedimento; 11.3.7. atos de efeitos concretos; II.3.8. verbetes de súmula de jurisprudência; 11.3.9. proposta de emenda constitucional; II.3.10. atos normativos que revogam ou sustam a eficácia de outro ato; II.3.11. medidas provisórias; 11.4. causa de pedir: não vinculação dos julgadores; II.5. pedido: II.5.1. vedação do julgamento extra ou ultra petita; II.5.2. inconstitucionalidade a fortiori de outros dispositivos decorrentes ou vinculados ao que foi declarado inconstitucional; II.6. efeitos da decisão: II.6.1. eficácia declaratória de nulidade do ato normativo (efeitos ex tunc); II.6.2. a declaração da inconstitucionalidade sem a pronúncia da nulidade (precedentes na ju-

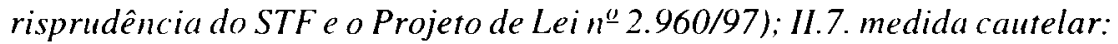

* Procurador do Estado do Rio de Janeiro e Advogado. Professor contratado de Direito Administrativo da Faculdade de Direito da Universidade do Estado do Rio de Janeiro - UERJ.

R. Dir. Adm.

Rio de Janeiro. 218: 151-174,

out./dez. 1999 
requisitos gerais e específicos; 11.7.I. efeitos da concessão da liminar. III. A ação direta de constitucionalidade em âmbito estadual: III.I. cabimento quando se trata de norma constitucional estadual que reproduz dispositivo da Constituição Federal; III.2. cabimento de recurso extraordinário e de suspensão de segurança. - IV. A ação declaratória de constitucionalidade: IV.I. o efeito vinculante (diferença em relação à ADIN?); IV.2. requisito de admissibilidade: divergência jurisprudencial sobre a constitucionalidade do ato normativo; IV.3. cabimento de medida cautelar, inobstante a ausência de previsão constitucional expressa (poder geral de cautela); IV.4. efeitos da concessão da liminar; IV.5. obrigatoriedade de contraditório? - V. Conclusão.

\section{O SISTEMA ECLÉTICO DE CONTROLE DA CONSTITUCIONALIDADE ADOTADO NO BRASIL: ORIGENS HISTÓRICAS E DESENVOLVIMENTO. O PROJETO DE LEI No 2.960/97}

Da primeira Constituição brasileira - a do Império, outorgada em 1824 - até a promulgada em 1988, atualmente em vigor, um longo caminho foi percorrido em matéria de controle de constitucionalidade.

Sob o influxo do ideário francês de rígida separação entre os poderes, a Carta imperial não contemplou qualquer sistema de controle judicial da constitucionalidade das leis. Em seu art. 15, $n^{2}$ s $8^{2}$ e $9^{9}$, outorgava ao Poder Legislativo a atribuição de fazer leis, interpretá-las, suspendê-las e revogá-las, bem como velar na guarda da Constituição. Consagrava-se, assim, ao menos em termos ideais, a supremacia do Parlamento sobre a Constituição. A existência do Poder Moderador, reconhecido ao monarca, longe de atenuar, antes agiavava ainda mais o desprestígio institucional da Lei maior. ${ }^{1}$

A conhecida influência do direito norte-americano sobre os artífices da Constituição republicana, especialmente Rui Barbosa, foi decisiva para a introdução do controle judicial difuso da constitucionalidade entre nós. ${ }^{2}$ Embora alguns autores cheguem a questionar a originalidade histórica do judicial review, ${ }^{3}$ fato é que o caso Marbury vs. Madison, julgado em 1803 pela Suprema Corte dos Estados Unidos, entrou para a história como o primeiro precedente da proclamação da superioridade hierárquica da Constituição sobre as demais leis e do consequiente poder dos juízes de não as aplicar quando contrárias ao texto constitucional.

1 MENDES, Gilmar Ferreira. A Evoluçāo do Direito Constitucional Brasileiro e o Controle de Constitucionalidade da Lei in Direitos Fundamentais e Controle de Constitucionalidade, 1998, p. $229 / 230$.

2 Idem. p. 231.

3 V. CAPPELLETTI, Mauro. O Controle Judicial de Constitucionalidade das Leis no Direito Comparado, 1992, p. 48 e segs. O autor demonstra que no Direito ateniense e na Idade Média já se concebia a idéia da "supremacia de uma dada lei ou de um corpo de leis". 
O direito constitucional brasileiro adota, desde a promulgação da Carta de 1891 . a técnica da aferição incidental da constitucionalidade das leis pelos órgãos do Poder Judiciário. Em caso de incongruência entre a lei e a Constituição, reconhece-se a Juízes e Tribunais o poder de negar aplicação àquela na solução dos litígios submetidos à sua cognição.

Segue-se, dai em diante, uma crescente ampliação do sistema de controle da constitucionalidade pátrio.

Não se olvide, entretanto, que este tipo de controle foi plagiado da matriz norte-americana, vinculada à tradição anglo-saxônica da common law. Assim, embora representando inegável avanço do ponto de vista democrático, pelo acesso direto à Constituição que proporciona às partes e aos Juízes, tal sistema exibiu, desde logo, algumas deficiências, decorrentes de sua adoção em um país herdeiro da tradição jurídica romano-germânica.

A multiplicidade de entendimentos entre os Juízes associada à inexistência do sistema de vinculação aos precedentes ("stare decisis"), como no direito anglo-saxônico, é fonte geradora de incerteza e insegurança jurídicas. Ademais, o sistema não solucionava o problema da necessidade de propositura de tantas ações quanto o número de interessados em determinada matéria, mesmo após a manifestação da Suprema Corte. ${ }^{4}$

A Constituição de 1934 inovou-o ao instituir, em seu art. 91, inciso IV, a competência do Senado Federal para suspender, no todo ou em parte, a execução de ato jurídico declarado inconstitucional pelo Supremo Tribunal Federal. Procurou-se, assim, dar efeito geral às decisões judiciais de inconstitucionalidade, corrigindo os inconvenientes do sistema puramente difuso. ${ }^{5}$

Após o eclipse autoritário do Estado Novo, sob cuja égide o Presidente Getúlio Vargas chegou a editar Decretos reafirmando a validade de textos de lei declarados inconstitucionais pelo Supremo Tribunal Federal, ${ }^{6}$ a Constituição de 1946 restaura a tradição do controle judicial no Direito brasileiro. ${ }^{7}$ A par da manutenção do sistema difuso e da competência do Senado Federal para suspender a execução de atos declarados inconstitucionais pelo Supremo Tribunal Federal, instituiu-se a chamada representação interventiva, que permitia a argüição, pelo Procurador-Geral da Re-

4 V. CAPPELLETTI, Mauro. O Controle Judicial de Constitucionalidade das Leis no Direito Comparado, 1992, p. 76/79. O autor expõe as deficiências geradas pela implantação do sistema norte-americano nos países da Europa continental, vinculados, tal como o Brasil, à tradição romano-germânica.

5 LOURENÇO, Rodrigo Lopes. Controle da Constitucionalidade à Luz da Jurisprudência do $S T F, 1998$, p. 11.

6 BITTENCOURT, Carlos Alberto Lucio. O controle jurisdicional da constitucionalidade das leis, 1968, p. 139/140. Vale destacar que a Constituiçāo de 1937, no parágrafo único de seu art. 96, dispositivo que permitia ao Presidente da República submeter ao Parlamento lei declarada inconstitucional. Caso a validade de tal lei fosse confirmada por dois terços de cada uma das Casas Legislativas, a decisão judicial deixava de produzir efeitos.

7 MENDES, Gilmar Ferreira. Ob. cit., p. 238. 
pública. da compatibilidade de ato normativo estadual com os chamados princípios constitucionais sensíveis.

Tal instrumento abriu caminho para a adoção, entre nós. do controle abstrato de normas, eis que suscitado independentemente da instauração de uma lide e cujo escopo essencial era a suspensão da eficácia do ato impugnado. ${ }^{9}$ Com efeito, o art. 13 da Constituição de 1946 dispunha que o Congresso Nacional deveria cingir-se a suspender a eficácia do ato atacado, caso tal medida fosse suficiente para reconduzir a situação à normalidade.

Somente com o advento da Emenda Constitucional no 16 , de 26 de novembro de 1965, é que foi introduzido no Brasil o controle abstrato de normas federais e estaduais, nos mesmos moldes da representação interventiva. Esta mesma Emenda instituiu, no art. 124, inciso XIII, da Constituição de 1946, a possibilidade de o legislador instituir processo de competência originária dos Tribunais de Justiça estaduais para a declaração de inconstitucionalidade de lei ou ato normativo estadual ou municipal em face da Constituição do Estado-membro.

A Carta outorgada de 1967 e a Emenda Constitucional nº 01/69 mantiveram a coexistência dos sistemas de controle difuso-incidental e concentrado-abstrato. A competência para a deflagração deste último permaneceu monopolizada pelo Procurador-Geral da República, o que, de certo modo, limitou a sua significação política e jurídica. Vale lembrar, por oportuno e relevante, que até o advento da Constituição de 1988 o Procurador-Geral da República era nomeado e exonerado ad nutum pelo Presidente da República, sendo certo que a Procuradoria Geral da República instituição que lhe incumbia chefiar - acumulava as funções de Ministério Público Federal com a representação judicial da União Federal. Esta dupla feição do cargo de Procurador-Geral da República, com certa submissão funcional à Chefia do Poder Executivo, explica, de certo modo, a timidez e parcimônia com que a representação por inconstitucionalidade foi utilizada até 1988.

A Emenda Constitucional $\mathrm{n}^{\mathfrak{Q}} 07 / 77$ instituiu a representação para fins de interpretação de lei ou ato normativo federal ou estadual, posteriormente extinta, e encerrou a controvérsia sobre a possibilidade da concessão de liminar em representação de inconstitucionalidade, reconhecendo-a de modo expresso.

A grande inovação instituída pela Constituição de 1988 foi a desmonopolização da legitimatio para a deflagração do controle abstrato da constitucionalidade. Confira-se, a este propósito, passagem significativa da lavra do Professor Luís Roberto Barroso, in verbis:

"De fato, o florescente desenvolvimento da jurisdição constitucional no Brasil se deveu, substancialmente, à ampliação da legitimação ativa para propositura da ação direta de inconstitucionalidade. No regime constitucional anterior, o Procurador-Geral da República detinha o monopólio da deflagração do controle abstrato

8 Eram eles: forma republicana representativa; independência e harmonia entre os poderes; temporariedade das funções eletivas; proibição da reeleição de governadores e prefeitos para período imediato: autonomia municipal; prestação de contas da administração; garantias do Poder Judiciário.

9 LOURENÇO, Rodrigo Lopes. Ob. cit., 1998, p. 13. 
de constitucionalidade, mediante oferecimento de representação, para utilizar a designação então empregada." 11

O Professor Gilmar Ferreira Mendes, a seu turno, ressalta, com acuidade, as conseqüências políticas ensejadas pela mudança, verbis:

"A ampla legitimação, a presteza e celeridade desse modelo processual, dotado inclusive da possibilidade de se suspender imediatamente a eficácia do ato normativo questionado, mediante pedido cautelar, faz com que as grandes questões constitucionais sejam solvidas, na sua maioria, mediante a utilização da ação direta, típico instrumento do controle concentrado.

A particular conformação do processo de controle abstrato de normas confere-lhe, também, novo significado como instrumento federativo, permitindo a aferição da constitucionalidade das leis federais mediante requerimento do Governador do Estado e a aferição da constitucionalidade das leis estaduais, mediante requerimento do Presidente da República.

A propositura da ação pelos partidos políticos com representação no Congresso Nacional concretiza, por outro lado, a idéia de defesa das minorias, uma vez que se assegura até às frações parlamentares menos representativas a possibilidade de argüir a inconstitucionalidade de lei." 11

A par disto, a Constituição de 1988 instituiu mecanismos de controle contra omissões normativas inconstitucionais, tanto em sede concreta (art. $\left.5^{\circ}, \mathrm{LXXI}\right)-0$ que seria (ou deveria ser) o mandado de injunção - como em sede abstrata (art. $\left.103, \S 2^{2}\right)-$ a ação direta de inconstitucionalidade por omissão.

A Emenda Constitucional n 03, de 17 de março de 1993, introduziu no sistema brasileiro a ação declaratória de constitucionalidade. Tal instituto, simetricamente à ADIN, tem por escopo propiciar a prolação de uma decisão do Supremo Tribunal Federal que afirme, com eficácia erga omnes e efeito vinculante, a constitucionalidade de determinada lei ou ato normativo. Por tal decisão, a presunção de constitucionalidade da lei, que é relativa, torna-se absoluta, impedindo a sua inobservância, sob o argumento de inconstitucionalidade, por quem quer que seja, inclusive pelos demais órgãos do Poder Judiciário e pelo Poder Executivo.

A notável produção jurisprudencial do STF em matéria de jurisdição constitucional à luz da Constituição de 1988 revela um significativo avanço do sentimento constitucional $^{12}$ no país. Apenas à guisa de ilustração, em pesquisa levada a efeito

10 BARROSO, Luís Roberto. Dez Anos da Constituição de 1988 (Foi bom pra você também?) in Revista de Direito Administrativo $\mathrm{n}^{0} 214,1998$, p. 15.

11 MENDES, Gilmar Ferteira. Ob. cit., p. 253.

12 Com grande entusiasmo o Professor Luís Roberto Barroso saúda tal avanço, in verbis: "O surgimento de um sentimento constitucional no País é algo que merece ser celebrado. Trata-se de um sentimento ainda tímido, mas real e sincero, de maior respeito e até um certo carinho pela Lei Maior, a despeito da volubilidade de seu texto. É um grande progresso. Superamos a crônica indiferença que, historicamente, se manteve em relação à Constitução. E para os que sabem, é a indiferença, não o ódio, o contrário do amor.", in Dez Anos da Constituição de 1988 (Foi bom pra você também? ') in Revista de Direito Administrativo n² 214, 1998, p. 25. Registre-se que a expressāo sentimento constitucional é devida a Pablo Lucas Verdu. 
no ano de 1996. o Supremo Tribunal Federal havia julgado. desde a promulgação da Carta até então. 1.746 ações diretas de inconstitucionalidade, ao passo que, nos 22 anos anteriores, entre 1966 e 1987, julgara apenas 726 processos de igual natureza. $^{13}$

Essa crescente judicialização do controle da constitucionalidade acabou por gerar, de outro lado, inúmeras discussões sobre os seus aspectos processuais, com ênfase nas suas especificidades em relação aos processos intersubjetivos.

A Emenda Constitucional $n^{\circ} 01 / 69$ previa, em seu art. 119, $\S 3^{2}$, alínea “c”, competência legislativa exclusiva do Supremo Tribunal Federal para dispor sobre o procedimento aplicável aos processos de sua competência originária e recursal. Assim, só o Regimento Interno da Corte podia dispor sobre o processo de controle da constitucionalidade.

Com o advento da Constituição de 1988, tal competência legislativa do Supremo Tribunal Federal desapareceu, passando a matéria à competência do legislador ordinário (CF, art. 22, inciso I). O Regimento Interno da Corte foi recepcionado, no que materialmente compatível com a nova Carta, com o status de lei ordinária. Todavia, suas disposições mostraram-se obsoletas e insuficientes face à extensão alcançada pelo controle abstrato de constitucionalidade após o advento da Constituição de 1988.

Visando a colmatar esta lacuna e a consolidar a jurisprudência do Supremo Tribunal Federal na matéria, foi apresentado ao Congresso Nacional o Projeto de Lei no 2.960/97, dispondo sobre o processo e julgamento da ação direta de inconstitucionalidade e da ação declaratória de constitucionalidade. Tal Projeto foi o resultado do trabalho de uma Comissão de juristas composta pelos Professores Ada Pelegrini Grinover, Álvaro Villaça de Azevedo, Antonio Jamyr Dall' Agnol, Arnoldo Wald, Carlos Alberto Direito, Gilmar Ferreira Mendes, Luís Roberto Barroso, Manoel André da Rocha, Roberto Rosas, Ruy Rosado de Aguiar Júnior e Antonio Herman Vasconcellos Benjamin e presidida pelo Professor Caio Tácito.

O propósito do presente estudo é o de vasculhar e, em certa medida, discutir a jurisprudência produzida pelo Supremo Tribunal Federal acerca dos aspectos processuais do controle abstrato da constitucionalidade, comentando, ademais, algumas das soluções propugnadas pelo Projeto de Lei nº $2.960 / 97$.

\section{A AÇÃO DIRETA DE INCONSTITUCIONALIDADE CONTRA ATOS COMISSIVOS}

\section{II.1. Natureza jurídica do processo}

Ao contrário dos processos intersubjetivos, em que as partes contendem em torno de direitos ou interesses em conflito, o processo de controle da constituciona-

13 V. MENDES, Gilmar Ferreira. O Poder Executivo e o Poder Legislativo no Controle da Constitucionalidade. COAD, Seleçōes Jurídicas, junho/1997, p. 33. 
lidade não envolve pessoas ou interesses concretos, cingindo-se à aferição, em tese. da compatibilidade de uma norma determinada com outra que lhe é hierarquicamente superior.

Diz-se, assim, que tal processo é objetivo ${ }^{14}$, no sentido de que não envolve situações jurídicas de caráter individual, destinado não à solução de litígios intersubjetivos, mas à guarda da Constituição ${ }^{15}$. O Supremo Tribunal Federal adota placidamente a tese acima ${ }^{16}{ }^{16}$ não sem algumas mitigações em determinados pontos, como adiante se verá. Uma delas refere-se à exigência da denominada pertinência temática como requisito de legitimação para a causa, consistente na demonstração da relação de pertinência direta entre a pretensão deduzida na ação e os objetivos institucionais do seu autor.

\section{II.1.1. Indisponibilidade da ação (vedação à desistência)}

O Regimento Interno do Supremo Tribunal Federal, em seu art. 169, $\S 1^{\circ}$, veda expressamente a desistência da ação direta de inconstitucionalidade, à vista de sua natureza objetiva e de seu caráter indisponível. Tal norma é reproduzida no art. 5o do Projeto de Lei $\mathrm{n}^{0} 2.960 / 97$. Com efeito, não há interesse individual em jogo a justificar o pedido de desistência, prevalecendo o interesse público de proteção da ordem jurídica e da Constituição. Por idêntica razão, não se admite a desistência de pedido liminar. ${ }^{17}$

Aliás, segundo o já mencionado art. $169, \S 1^{2}$ do Regimento Interno do Supremo Tribunal Federal, ao Procurador-Geral da República não é dado desistir da ação,

14 MENDES, Gilmar Ferreira. Controle de Constitucionalidade - Aspectos Jurídicos e Políticos, 1990 , p. 250/251. Segundo o autor, o processo objetivo é "um processo sem sujeitos, destinado, pura e simplesmente, à defesa da Constituiçāo. Não se cogita, propriamente, da defesa de interesse do requerente, que pressupõe a defesa de situaçōes subjetivas."

15 Rodrigo Lopes Lourenço, na sua obra acima citada, aponta as consequiências jurídicas que, a seu ver, decorrem deste entendimento: a) inexistência de litisconsórcio ou assistência, uma vez que o processo não tem partes e não envolve situações subjetivas; b) inexistência de suspeição dos julgadores; c) ocorrência de impedimento somente na hipótese em que o julgador houver atuado, no mesmo processo, como requerente, requerido, Procurador-Geral da República ou AdvogadoGeral da Uniāo; d) descabimento da açāo se a norma impugnada for anterior à Constituição; e) extinçāo da açāo direta caso a norma impugnada seja revogada no curso do procedimento; ) reconhecimento da capacidade postulatória aos entes elencados no art. 103, I a V, da Constituição Federal.

16 “(...) no exercício do controle em abstrato da norma jurídica, o Supremo Tribunal Federal desempenha funçāo política, em cujo âmbito instauram-se relações processuais objetivas, que visam à tutela da ordem constitucional, sem vinculações quaisquer a situaçōes de caráter individual, sendo a Corte investida numa competência de exclusāo, consistente na remoçāo da manifestação estatal inválida do ordenamento jurídico, desempenhando, pois, o papel de legislador negativo." (RTJ n 131/1001 e 146/461).

17 ADIN nํㅛ 892-RS, rel. Min. Celso de Mello, DJU 07.11.1997. 
ainda que. ao final, seu parecer seja pela constitucionalidade da norma inicialmente impugnada. ${ }^{1 \times}$

\section{II.1.2. Hipóteses restritas de parcialidade dos julgadores}

Como não há partes propriamente ditas, nem tampouco interesses subjetivos em jogo, não há cogitar de suspeição dos magistrados. Outrossim, impedimento só haverá na hipótese em que algum dos julgadores houver atuado no feito que the competiria julgar como requerente, requerido, Procurador-Geral da República ou Advogado-Geral da União. ${ }^{19}$

\section{II.1.3. Inexistência de fase instrutória (controvérsias)}

Costuma-se dizer ${ }^{20}$ - e esta tem sido mesmo a posição do Supremo Tribunal Federal $^{21}$ - que a ação direta não comporta dilação probatória, à vista de seu caráter estritamente objetivo. Todavia, o Projeto de Lei $\mathrm{n}^{\circ} 2.690 / 97$ desmistifica tal idéia, prevendo, em seus arts. $9^{\circ}, \S 1^{0}$ e $20, \S 1^{2}$, a possibilidade de o relator, em caso de necessidade de esclarecimento de matéria ou circunstância de fato ou de notória insuficiência das informações existentes nos autos, requisitar informações adicionais, designar perito ou comissão de peritos para que emita parecer sobre a questão, ou fixar data, para, em audiência pública, ouvir depoimentos e pessoas com experiência e autoridade na matéria.

Como relata a exposição de motivos do Projeto de Lei, nos Estados Unidos, o chamado "Brandeis-Brief”- memorial utilizado pelo advogado Louis D. Brandeis, no case Müller vs. Oregon (1908), contendo duas páginas dedicadas às questões jurídicas e outras 110 voltadas para os efeitos da longa duração do trabalho sobre a situação da mulher - permitiu que se desmistificasse a concepção dominante, segundo a qual a questão constitucional configurava simples "questão jurídica" de aferição de legitimidade da lei em face da Constituição.

A inovação do Projeto é bem inspirada, uma vez que há, com efeito, casos em que a apreciação da constitucionalidade de uma norma depende do esclarecimento sobre fatos relativos à sua produção, forma de incidência e repercussão prática. Igualmente louvável a previsão de diligência pericial, que pode se tornar necessária na apreciação de leis que cuidem de questões técnicas muito específicas, inacessíveis ao leigo. Nada obstante, a utilização de meios de prova previstos no Código de Processo Civil é possível, a juízo do relator, independentemente de previsão legal específica.

18 Regimento Interno do STF, art. 169, § 1ّ: "Proposta a representação, não se admitirá desistência, ainda que afinal o Procurador-Geral se manifeste pela sua improcedência."

19 RTJ 146/3 e 147/719.

20 LOURENÇO, Rodrigo Lopes. Ob. cit., p. 31.

21 ADIN n" 1286-SP, rel. Min. Ilmar Galvão, DJU 06.09.1996. 


\section{II.2. Partes}

O termo parte é utilizado, em sede de controle abstrato da constitucionalidade, por analogia com a Teoria Geral do Processo. De fato, como já assinalado, o processo de controle de constitucionalidade não envolve pessoas e interesses concretos, razão pela qual é qualificado como processo objetivo. Autores serão, assim, os entes legitimados pela Constituição para deflagrar a instauração do processo, preenchidos os requisitos processuais pertinentes. Réus serão, a seu turno, as autoridades públicas responsáveis pela produção da norma jurídica cuja validade é questionada.

\section{II.2.1. Pertinência temática}

Embora a Constituição não a preveja, o Supremo Tribunal Federal produziu, nos últimos anos, uma robusta jurisprudência erigindo a pertinência temática como requisito específico para que determinados entes e órgãos possam manejar a ação direta de inconstitucionalidade.

Entende-se por pertinência temática uma relação de pertinência entre as prerrogativas ou fins institucionais do órgão ou entidade legitimado para a propositura da ação direta com aquele ato normativo por meio dela questionado. A idéia da pertinência temática surgiu quando do excesso de ações diretas de inconstitucionalidade propostas por confederações sindicais e entidades de classe de âmbito nacional. Assim, uma associação destinada à proteção de animais silvestres não poderia ajuizar uma ADIN questionando a constitucionalidade da lei que instituiu o IPMF.

Da mesma forma, isso vem sendo aplicado aos Governadores de Estados e Mesas de Assembléias Legislativas. O Governador do Estado do Rio de Janeiro, em princípio, tem legitimidade para propor ADIN questionando a constitucionalidade de leis do seu Estado. É possível, no entanto, vislumbrar exceções a tal regra, desde que caracterizada a relação de pertinência entre o interesse estadual e a lei - federal ou estadual - objeto da ADIN. Figure-se um exemplo para melhor compreensão: suponha-se uma lei do Estado de São Paulo, ou de qualquer outro Estado, que, dispondo sobre o ICMS interestadual, venha a interferir diretamente na arrecadação do Estado do Rio de Janeiro. Aí, evidentemente, estaria configurada a relação de pertinência temática e o Governador do Estado do Rio de Janeiro estaria legitimado a propor essa ADIN.

Vale notar que o parágrafo único do art. $2^{\circ}$ do Projeto de Lei $\mathrm{n}^{\mathrm{Q}} 2.960 / 97$ restringe a exigência da pertinência temática às confederações sindicais e entidades de classe de âmbito nacional, o que, de certo, não impedirá o Supremo Tribunal Federal de exigi-la nas ações propostas por Governadores e Mesas de Assembléias Legislativas.

A jurisprudência do Supremo Tribunal Federal já era tranqüila em dispensar tal requisito nas ações diretas ajuizadas pelo Conselho Federal da OAB e por partidos políticos, cuja missão institucional é a defesa da ordem jurídica como um todo. 


\section{II.2.2. Capacidade postulatória}

O Supremo Tribunal Federal entende que os entes elencados nos incisos I a VII do art. 103 da Constituição detêm capacidade postulatória plena para ajuizarem ação direta de inconstitucionalidade, independentemente da constituição de advogado. Quanto aos partidos políticos, confederações sindicais e entidades de classe de âmbito nacional, entende-se que necessitam do patrocínio advocatício. ${ }^{22}$

\section{II.2.3. Confederaçāo sindical e entidade de classe de âmbito nacional}

Quanto às entidades de classe de âmbito nacional, o Supremo Tribunal Federal vem impondo algumas exigências para a caracterização do caráter nacional. Com efeito, por analogia com a Lei Orgânica dos Partidos Políticos (Lei Federal $\mathrm{n}^{\mathrm{o}}$ $9.096 / 95$ ), art. $7^{\circ}, \S 1^{2}$, a Suprema Corte exige que a entidade de classe, para que se lhe reconheça o caráter nacional, tenha atuação em pelo menos nove Estados número exigido pela Lei para que o partido político seja considerado de âmbito nacional. ${ }^{23}$ Exige-se, ainda, cumulativamente, que as entidades de classe: (I) sejam formadas por pessoas naturais ou pessoas jurídicas que componham uma categoria profissional ou econômica diferenciada; (II) componham uma categoria homogênea; e (III) não se configurem como "associações de associações". ${ }^{24}$

Exige-se das confederações sindicais, obrigatoriamente, o registro competente junto ao Ministério do Trabalho. ${ }^{25}$

\section{II.2.4. Litisconsórcio, assistência e outras formas de intervençäo de terceiros}

É admissível, em tese, a pluralidade de autores e réus na ação direta de inconstitucionalidade. Assim, v.g., nada impediria o ajuizamento de uma ADIN por dois ou mais entes legitimados em conjunto (litisconsórcio ativo). De outro lado, havendo sido editado por mais de um órgão o ato normativo atacado na ADIN, todos serão réus no processo (litisconsórcio passivo).

Não há sentido, de outra parte, em cogitar de assistência na ação direta de inconstitucionalidade, por isto que se trata de um processo objetivo, sem que haja em discussão um interesse concreto das partes. De fato, não havendo interesse concreto em litígio, não pode haver interesse jurídico a ensejar a intervenção de um terceiro na relação processual.

22 RTJ $144 / 3$.

23 RTJ $129 / 959,136 / 479,141 / 3$ e $147 / 372$.

24 RTJ 132/561, 138/81, 138/421, 139/378, 155/97, 155/416 e 161/89.

25 RTJ $150 / 707$ e $159 / 413$. 
Inspirado na idéia acima delineada, o art. 169. § 2․ do Regimento Interno do Supremo Tribunal Federal veda expressamente a assistência. O caput do art. $7^{\circ}$ do Projeto de Lei $\mathrm{n}^{\mathrm{0}}$ 2.690/97 veda, de forma genérica, a intervenção de terceiros no processo de ação direta de inconstitucionalidade.

\section{II.2.5. A figura do amicus curiae}

$\mathrm{O}$ art. $7^{\circ}, \S 2^{\circ}$, do Projeto de Lei visa a positivar a figura do amicus curiae. Se, de um lado, por rigor técnico, não se admite a intervenção de terceiros, reconhece-se, de outro, a possibilidade de o relator, considerando a relevância da matéria e a representatividade dos postulantes, aceitar a manifestação no processo de outros órgãos ou entidades, que tenham algum tipo de interesse (não jurídico) no desfecho do processo.

Tal norma vem positivar a jurisprudência do Supremo Tribunal Federal sobre o tema, que sempre admitiu a apresentação de memoriais pelos interessados, de qualquer modo, no julgamento da ação direta.

\section{II.2.6. O papel do Advogado-Geral da União}

Cabe ainda tecer comentários sobre o papel desempenhado pelo Advogado-Geral da União na ação direta de inconstitucionalidade.

O Advogado-Geral da União tem sempre que ser citado para defender o ato impugnado (art. 103, § $3^{2}$ ). Sua atribuição ordinária, todavia, é a defesa da União Federal. Imagine-se, então, a seguinte hipótese: uma ação direta proposta contra uma lei estadual sob o argumento de que ela é inconstitucional porque invade a esfera de competências da União Federal. O Advogado-Geral da União, apesar de exercer a chefia da instituição responsável pela defesa em juízo da União Federal, deve defender aquele ato estadual, como determina a Constituição?

A resposta é afirmativa. É que a competência do Advogado-Geral da União tem sede constitucional, assim como a disciplina da Advocacia-Geral da União. Assim, entre duas normas de mesma hierarquia - e são normas de mesma hierarquia porque ambas estão previstas no texto constitucional —, é preciso aplicar o princípio da especialidade, que é aquele que determina que, diante de duas normas, uma genérica e outra específica, prevaleça, para o caso específico, a norma específica. E qual é a norma específica neste caso? Aquela que determina que o Advogado-Geral da União defenda a lei - federal ou estadual — independentemente do fundamento pelo qual se questione a sua constitucionalidade.

Pode-se dizer que o Advogado-Geral da União exerce a defesa do ato impugnado apenas para garantia do contraditório. Atua ele como uma espécie de curador da presunção de constitucionalidade das leis, independentemente de sua origem federal ou estadual. 
Como já acima mencionado, os partícipes na elaboração do ato normativo impugnado pela ADIN são os réus do processo. Assim, havendo sancionado o projeto de lei, responderá como réu o Chefe do Poder Executivo, ao lado da Casa Legislativa. Caso o tenha vetado, não participará da relação processual.

Resta a questão: é possível que o Presidente da República, ou qualquer Governador de Estado, havendo sancionado um determinado projeto de lei, venha, depois disto, a ajuizar uma ADIN, sob o argumento de que aquela lei é inconstitucional?

Ao que parece, em primeira leitura, não há nenhum impedimento a que o Presidente da República ou os Governadores de Estado o façam. Em primeiro lugar, a legitimidade desses órgãos para o ajuizamento da ação direta de inconstitucionalidade não é condicionada de nenhuma forma pela Constituição. Assim, não caberia ao intérprete e aplicador da Constituição restringir o que não foi objeto de restrição por parte do legislador constituinte. Em segundo lugar, se o Chefe do Poder Executivo sancionou a lei e entendeu que estava errado, é melhor que proponha a ação direta do que persistir no erro, cumprindo uma lei inconstitucional.

O que o Supremo Tribunal Federal tem entendido, em alguns acórdãos, é que o ato normativo sujeito a sanção ou veto do Presidente da República, Governadores e Prefeitos - alguns atos normativos não se sujeitam a sanção ou veto - é produto de uma vontade conjugada, das Casas Legislativas e do Chefe do Poder Executivo. É, assim, um ato complexo: a Casa Legislativa aprovando um projeto de lei encaminha-o ao Chefe do Executivo, que poderá sancioná-lo ou vetá-lo. Caso o Chefe do Poder Executivo o sancione, o projeto se converterá em lei.

Posteriormente, uma determinada ADIN é ajuizada questionando a constitucionalidade desta lei. Quem são os réus nesta ação? Os responsáveis pela edição daquele ato normativo, isto é, a Casa Legislativa - em nível federal, o Congresso Nacional -, e o Chefe do Executivo, que sancionou o projeto de lei. O Supremo Tribunal Federal vem entendendo o seguinte: não é razoável que o Presidente da República, sendo o réu de uma ADIN, porque participou da elaboração da lei impugnada possa figurar como autor da mesma ADIN. ${ }^{26}$

Ora, esse é um argumento que parece, à primeira vista, muito consistente. Haveria uma incompatibilidade, senão processual, pelo menos lógica, em o Presidente da República sancionar uma lei - e portanto ser réu na ação direta - e posteriormente pretender ser o seu autor.

Nada obstante, opõe-se a este entendimento uma observação que o próprio Supremo Tribunal Federal considera legítima. É que foi importada, do direito cons-

26 ADIN n" 807, rel. Min. Celso de Mello, DJU 11.06.93, verbis: “(...) Quando o ato normativo impugnado em sede de fiscalização abstrata tiver emanado tainbém do Chefe do Poder Executivo - a lei, sendo ato estatal subjetivamente complexo, emerge da conjugação das vontades autônomas do Legislativo e do Executivo - e este figurar, em conseqüência, no pólo passivo da relação processual, tornar-se-á juridicamente impossivel o seu ingresso em condição subjetiva diversa daquela que já ostenta no processo." 
titucional alemão para o brasileiro, a noção de que a ação direta de inconstitucionalidade constitui um processo objetivo, como acima já comentado. Como tal se entende o processo sem partes propriamente ditas, aquele em que não há, de cada lado, uma parte discutindo um direito subjetivo seu. Há, na verdade, um processo intelectivo, em que se afere a constitucionalidade de uma lei em tese. Ora, se o processo é objetivo, e o Supremo Tribunal Federal vem afirmando reiteradas vezes que o é, não há nenhum óbice a que o Chefe do Poder Executivo possa intentar a ADIN nas circunstâncias ora cogitadas, porque ele não defende nesse processo nenhum direito próprio.

$\mathrm{Na}$ verdade, o Chefe do Executivo apenas deflagra o processo, apresentando um questionamento quanto à constitucionalidade de uma determinada lei. Tanto é assim que o Procurador-Geral da República pode propor uma ADIN e, ao cabo do processo, opinar pela sua improcedência. Então, isso comprova não haver nenhum óbice de natureza processual a que o Presidente da República, mesmo tendo sancionado um projeto de lei, venha a propor a ADIN. Trata-se de interpretar as normas processuais de acordo com a Constituição, e não a Constituição de acordo com o Código de Processo Civil.

\section{II.3. Objeto}

\section{II.3.1. O significado da expressão "lei ou ato normativo"}

A expressão "lei ou ato normativo", constante do inciso I, alínea "a" do art. 102 da Constituição, não abrange, evidentemente, os atos normativos não-estatais, como convenções de condomínio ou estatutos de clubes ou empresas. ${ }^{27} \mathrm{O}$ objeto da ação direta de inconstitucionalidade é um ato estatal, editado após a Constituição de 05.10 .88 , por órgão federal, estadual ou distrital no exercício de competência estadual, com caráter normativo de $1^{\circ}$ grau.

\section{II.3.2. Atos normativos de $2^{\circ}$ grau}

Considera-se ato normativo o ato jurídico editado por órgão estatal, abstrato, geral e imperativo. Além das leis, poderá caber ação direta contra atos administrativos normativos ditos autônomos - isto é, aqueles que não visam a regulamentar uma lei - desde que contrariem diretamente algum dispositivo constitucional, como é o caso de alguns Decretos, Portarias Ministeriais, Resoluções de Tribunais, entre outros..$^{28}$ Caso se trate de ato normativo regulamentar, entende o Supremo Tribunal Federal que a eventual incompatibilidade será verificada com a lei, e não diretamente 
com a Constituição. O vício, nesta última hipótese, será de ilegalidade, e não de inconstitucionalidade.

\section{II.3.3. Atos normativos municipais}

A letra expressa do art. 102, I, "a”, da Constituição exclui a possibilidade de controle da compatibilidade das normas municipais em face da Constituição Federal. Nada obstante, é possível o controle em face da Constituição do Estado, ainda que a norma constitucional estadual constitua mera reprodução da norma constitucional federal. ${ }^{29}$

\section{II.3.4. Atos normativos distritais}

Outra questão já pacificada pela produção jurisprudencial do Supremo Tribunal Federal é a da possibilidade de o Governador do Distrito Federal propor ação direta de inconstitucionalidade. Por que se discute isso? Porque não está o Governador do Distrito Federal incluído, de forma expressa, no elenco do art. 103 da Constituição Federal. E tal elenco afigura-se evidentemente taxativo.

O Distrito Federal é um ente da Federação anômalo, que tem algumas características de Estado e outras de Município. $O$ art. 32, § 1ำ da Constituição assim dispõe: "Ao Distrito Federal são atribuídas as competências legislativas reservadas aos Estados e Municípios".

O Distrito Federal exerce, portanto, competências legislativas estaduais. Por outro lado, a ADIN pode ter por objeto tanto leis federais como estaduais. E mais: o art. 103 da CF assegura aos Governadores de Estado a possibilidade de ajuizarem a ADIN contra leis estaduais. Por que, então, o Governador do Distrito Federal não poderia propor ação direta questionando a constitucionalidade de ato normativo distrital?

A solução adotada pelo Supremo Tribunal Federal - e que se afigura correta - é a de que o Governador do Distrito Federal é assemelhado, para fins de propositura de ADIN, aos Governadores de Estado. Não há nada que os diferencie, tanto que a Constituição dispõe que aqueles devem ser eleitos da mesma forma e com o mesmo procedimento que os Governadores de Estado (art. 32, § $2^{\circ}$ ). E, mais do que isso, não há razão para excluir do controle concentrado de constitucionalidade as normas do Distrito Federal editadas no exercício de competência estadual. Assim, v.g., uma lei do Distrito Federal que disponha sobre um tributo estadual pode ser objeto de ADIN.

Esta, precisamente, a posição adotada pelo Supremo Tribunal Federal ${ }^{30}:$ sendo uma lei distrital que tenha conteúdo estadual, poderá ser objeto de ADIN. E sendo

30 ADIN n² 645-2, rel. Min. Ilmar Galvāo. DJU de 21.02.92, p. 1.693. V. também ADIN n² 665, 
municipal? Evidentemente que não, porque a Constituição Federal não admite que o controle concentrado de constitucionalidade. perante o Supremo Tribunal Federal, seja exercido contra leis municipais.

\section{II.3.5. Atos normativos anteriores à Constituição}

É pacífico o entendimento do Supremo Tribunal Federal no sentido de que as leis anteriores à Constituição não se alçam ao controle abstrato de constitucionalidade. De fato, predomina o entendimento de que a finalidade do controle abstrato é apenas retirar do ordenamento jurídico o ato normativo incompatível com a Lei maior. Deste modo, sendo o ato normativo anterior ao texto constitucional, aquele simplesmente foi revogado - ou não foi recepcionado - por este último. A questão não estaria, assim, no plano da validade (constitucionalidade), mas no da existência (revogação). ${ }^{31}$ Deste modo, a única forma de perquirir judicialmente sobre a adequação de normas anteriores à Constituição com seus princípios e regras seria por meio do controle incidental.

\section{II.3.6. Atos normativos revogados antes ou no curso do procedimento}

$\mathrm{Na}$ mesma linha de raciocínio, revogada a lei antes ou durante a tramitação da ação direta, fica inviabilizado o controle abstrato. De uma ou outra forma, a norma já foi retirada do ordenamento jurídico, pouco importando que haja produzido efeitos. A solução de situações concretas não se dá no âmbito do controle abstrato, mas individualmente, por meio do controle incidental. ${ }^{32}$

\section{II.3.7. Atos de efeitos concretos}

Nenhum ato de efeito concreto, ainda que veiculado por lei formal, poderá ser objeto de ação direta de inconstitucionalidade. ${ }^{33} \mathrm{~A}$ jurisprudência, por isto mesmo, admite o cabimento de mandado de segurança contra leis de efeitos concretos, permitindo a tutela de interesses individuais. ${ }^{34}$

rel. Min. Octávio Gallotti. DJU de 24.04.92, p. 5.376.

31 RTJ 140/383, 140/405, 140/407, 140/754, 141/14, 141/50, 141/56, 141/362, 142/22, 142/43, $142 / 363,143 / 3,143 / 355,144 / 69,145 / 339,145 / 491$ e $147 / 372$.

32 RTJ $145 / 136$ e $160 / 796$.

33 RTJ 131/1001, 135/905, 138/436, 139/73, 140/36, 141/739, 146/483, 147/82, 152/742, 153/765, $156 / 767$ e $159 / 775$.

34 ADIN n" 1434-SP, rel Min. Celso de Mello, verbis: "Controle Abstrato de Constitucionalidade

- Processo de caráter objetivo - Impossibilidade de discussāo de situações individuais e concretas. O controle normativo da constitucionalidade qualifica-se como típico processo de caráter objetivo, vocacionado, exclusivamente, à defesa, em tese, da harmonia do sistema constitucional. 
Nada obstante tal entendimento. o STF tem admitido o cabimento de ação direta de inconstitucionalidade contra lei que cria município, cujo efeito de caráter concreto é inegável. ${ }^{35}$

\section{II.3.8. Verbetes de súmula de jurisprudência}

Não dispondo os verbetes de súmula de jurisprudência, no direito brasileiro, de caráter imperativo e vinculante para a generalidade dos casos, não se submetem ao controle abstrato de constitucionalidade, eis que lhes falta o essencial conteúdo normativo genérico e abstrato. ${ }^{36}$

\section{II.3.9. Proposta de emenda constitucional}

Ao contrário das normas emanadas do Poder Constituinte originário, as emendas constitucionais podem ser objeto de ação direta de inconstitucionalidade, desde que violados os limites circunstanciais (CF, art. $60, \S 1^{2}$ ) ou materiais (art. $60, \S 4^{2}$ ) para sua edição, ou subvertido o seu processo de elaboração legislativa. Não se admite, todavia, o cabimento de ADIN contra Proposta de Emenda Constitucional, ainda que contenha tais vícios, por isto que ainda não se trata de ato normativo perfeito e acabado.

Excepcionalmente, admite a Suprema Corte o cabimento de mandado de segurança contra a tramitação de Proposta de Emenda Constitucional tendente a abolir qualquer das chamadas "cláusulas pétreas", previstas no art. $60, \S 44^{2}{ }^{37}$ Tal entendimento decorre do disposto no $\S 4^{\mathfrak{Q}}$ do art. 60 , segundo o qual "não será objeto de deliberação a proposta de emenda tendente a abolir (...)". Segundo o Supremo Tribunal Federal, os parlamentares que se opuserem à tramitação de Proposta de Emenda Constitucional tendente a abolir qualquer uma das cláusulas pétreas poderão impetrar mandado de segurança contra o ato da Mesa da Casa Legislativa que houver admitido a tramitação da Proposta.

\section{II.3.10. Atos normativos que revogam ou sustam a eficácia de outro ato}

A declaração da inconstitucionalidade de ato normativo que revoga ou susta a eficácia de outro ato tem como consequiência lógica o restabelecimento, com eficácia

A instauração desse processo objetivo tem por função instrumental viabilizar o julgamento da validade abstrata do ato estatal em face da Constituição da República. O exame de relaçōes jurídicas concretas e individuais constitui matéria juridicamente estranha ao domínio do processo de controle concentrado de constitucionalidade."

35 RTJ $158 / 34$.

36 RTJ $151 / 20$.

37 RDA $183 / 158$. 
ex tunc. deste último. Com efeito, equiparando-se a lei inconstitucional ao ato nulo, impõe-se reconhecer a sua inaptidão para a produção de qualquer efeito válido, inclusive a revogação de outra lei. Observe-se que não se trata, aqui, de efeito repristinatório, mas de mera consequiência da nulidade $a b$ ovo da lei declarada inconstitucional.

\section{II.3.11. Medidas provisórias}

Não há dúvida quanto à admissibilidade do controle abstrato com relação às medidas provisórias, que são atos normativos, com força de lei, editados pelo Presidente da República.

Rejeitada a medida provisória pelo Congresso ou transcorrido in albis o prazo para sua apreciação, resta prejudicada a ação. Caso seja convertida em lei ou reeditada, sem alteração substancial do seu teor, admite o Supremo Tribunal Federal o aditamento da exordial de modo a permitir o prosseguimento da ação. ${ }^{38}$

O Supremo Tribunal Federal vinha reiterando sua antiga jurisprudência, firmada em relação ao decreto-lei, no sentido de não caber ao Poder Judiciário a apreciação da concorrência dos requisitos de relevância e urgência para a edição de medidas provisórias. Todavia, recentemente, tal posicionamento foi atenuado, com a suspensão da eficácia de um dispositivo que conferia maior prazo à Fazenda Pública para o ajuizamento de ação rescisória "pela falta de urgência necessária à edição da medida provisória impugnada." 39

\section{II.4. Causa de pedir: não vinculação dos julgadores}

A Corte constitucional não está vinculada aos fundamentos apontados na petição inicial da ação direta. Assim, embora rejeitando os fundamentos do autor, poderá declarar a inconstitucionalidade da norma impugnada por razões jurídicas diversas. ${ }^{40}$ Não se admite, todavia, que a petição inicial da ADIN se limite a pedir a declaração $\mathrm{da}$ inconstitucionalidade, sem apontar os fundamentos jurídicos que justificam a postulação.

\section{II.5. Pedido}

\section{II.5.1. Vedação do julgamento extra ou ultra petita}

Não pode o Supremo Tribunal Federal, no entanto, julgar além ou diferentemente do que foi pedido pelo autor da ação direta de inconstitucionalidade. Com 
efeito. não está a Corte autorizada a agir ex officio. uma vez que não está incluída no rol de legitimados para a deflagração do controle abstrato da constitucionalidade estabelecido no art. 103 da Constituição Federal.

\section{II.5.2. Inconstitucionalidade a fortiori de outros dispositivos decorrentes ou vinculados ao que foi declarado inconstitucional}

Hipótese diversa ocorre quando a petição inicial é silente a respeito dos dispositivos que regulamentam a norma legal impugnada. Aqui, por uma razão lógica, declarada a inconstitucionalidade do supedâneo legal, devem ser estendidos os efeifos da declaração a todas as normas que dele decorram, ainda que não contempladas expressamente na peça vestibular da ação.

\section{II.6. Efeitos da decisão}

\section{II.6.1. Eficácia declaratória de nulidade do ato normativo (efeitos ex tunc)}

Embora não haja norma expressa no direito brasileiro, a doutrina e a jurisprudência entendem, quase unanimemente, que a lei inconstitucional é ato nulo, daí decorrendo o caráter declaratório e retroativo da decisão proferida na ação direta de inconstitucionalidade ${ }^{41}$. Segue-se daí que nenhum efeito válido é reconhecido à lei desde a sua edição.

\section{II.6.2. A declaração da inconstitucionalidade sem a pronúncia da nulidade}

Consta do art. 27 do Projeto de Lei $\mathrm{n}^{2} 2.690 / 97$ que "ao declarar a inconstitucionalidade de lei ou ato normativo, e tendo em vista razões de segurança jurídica ou de excepcional interesse social, poderá o Supremo Tribunal Federal, por maioria de dois terços de seus membros, restringir os efeitos daquela declaração ou decidir que ela só tenha eficácia a partir do seu trânsito em julgado ou de outro momento que venha a ser fixado."

O propósito do preceptivo é o de introduzir no direito brasileiro a chamada declaração de inconstitucionalidade sem pronúncia da nulidade, prevista no $\$ 31$ da Lei Orgânica do Tribunal Constitucional Federal alemão. Em alguns casos, a jurisprudência alemã chega a admitir que a norma já declarada inconstitucional continue a viger até que o legislador produza nova regra em sua substituição.

Com lucidez, Daniel Sarmento sustenta a aplicação do princípio da proporcionalidade pela Corte Suprema na definição da eficácia temporal da decisão de incons-

4 V. MENDES, Gilmar Ferreira. Jurisdiçāo Constitucional, 1996, p. 249. 
titucionalidade. levando em conta os interesses em jogo. O próprio Supremo Tribunal Federal, aliás. já restringiu, em certos casos, a eficácia ex tunc de suas decisões, em benefício de outros valores que mereciam ser preservados. ${ }^{43}$

A admissão da declaração de inconstitucionalidade sem pronúncia da nulidade importa, a fortiori, o reconhecimento de que determinada norma, contrária à Constituição, produziu, durante certo lapso de tempo, efeitos válidos. Seria o art. 27 do Projeto de Lei, acima transcrito, compatível com o princípio da supremacia da Constituição? Não estaria ele permitindo que determinada norma infraconstitucional se sobreponha à Constituição durante certo período? Não é difícil vislumbrar que o aludido dispositivo deverá enfrentar sérias objeções quanto à sua constitucionalidade, tanto em sede doutrinária como jurisprudencial.

Resta, por fim, mencionar o apelo ao legislador, que constitui outra forma de controle de constitucionalidade das normas sem a pronúncia de sua nulidade, porém de caráter preventivo. Aqui, a Corte reconhece a constitucionalidade da norma, mas alerta o legislador para o fato de que, face às mudanças fáticas ou jurídicas, encontra-se ela em trânsito para a inconstitucionalidade. Embora se declare a validade da norma, exorta-se o legislador a que proceda à sua correção, sob pena de configuração futura da sua inconstitucionalidade. ${ }^{44}$

\section{II.7. Medida cautelar: requisitos gerais e específicos}

Como qualquer medida cautelar, a concessão da liminar em ação direta de inconstitucionalidade está sujeita aos requisitos genéricos de plausibilidade da pretensão (fumus boni iuris) e perigo na demora da decisão definitiva (periculum in mora). Rodrigo Lopes Lourenço colaciona hipóteses em que o Supremo Tribunal Federal tem negado a liminar, por ausência de periculum in mora: a) decurso de longo tempo desde a edição da norma impugnada; b) risco elevado de prejuízos caso concedida a liminar, superiores aos decorrentes do seu indeferimento; c) lei inquinada de inconstitucional é meramente autorizativa ou de eficácia limitada à ulterior edição de norma regulamentadora. ${ }^{45}$

Em alguns casos, entretanto, o Supremo Tribunal Federal tem mitigado a exigência do periculum in mora, substituindo-o pela conveniência administrativa do

42 SARMENTO, Daniel. Eficácia Temporal do Controle de Constitucionalidade (O Principio da Proporcionalidade e a Ponderação de Interesses) das Leis, in Revista de Direito Administrativo $\mathrm{n}^{2} 212$, p. 31.

43 RE 122.202, rel. Min. Francisco Rezek, DJU 08.04.94, in verbis: "Jurisprudência do STF no sentido de que a retribuição declarada inconstitucional não é de ser devolvida no periodo de validade inquestionada da lei de origem - mas tampouco paga após a declaração de inconstitucionalidade."

44 MENDES, Gilmar Ferreira. Jurisdição Constitucional, 1996, p. 229/230.

45 LOURENÇO, Rodrigo Lopes. Ob. cit., p. 84. 
deferimento da liminar. ${ }^{\text {th }}$ Tal artifício tem servido para evitar que normas teratológicas editadas há muito tempo permaneçam produzindo efeitos.

\section{II.7.1. Efeitos da concessão da liminar}

Em regra, a concessão da liminar pelo Supremo Tribunal Federal em sede de ADIN opera efeitos apenas ex nunc. Todavia, a Corte vem, recentemente, mitigando tal orientação, já havendo concedido liminares em ações diretas com efeitos retroativos. $^{47}$

\section{A AÇÃO DIRETA DE CONSTITUCIONALIDADE EM ÂMBITO ESTADUAL}

\section{III.1. Cabimento quando se trata de norma constitucional estadual que reproduz dispositivo da Constituição Federal}

Estabelece a Constituição Federal, em seu art. 125, § 2o, que "cabe aos Estados a instituição de representação de inconstitucionalidade de leis ou atos normativos estaduais ou municipais em face da Constituição Estadual, vedada a atribuição da legitimação para agir a um único órgão."

Surgiu, desde logo, com a promulgação das Cartas estaduais, a questão de saber se era possível a deflagração do controle concentrado perante o Tribunal de Justiça quando a norma constitucional estadual fosse mera reprodução de norma da Constituição Federal. O cerne da controvérsia era apurar se o Tribunal local não estaria usurpando uma competência do Supremo Tribunal Federal, eis que a norma apontada como violada era de matriz federal.

A jurisprudência do Supremo Tribunal Federal reconheceu a legitimidade de tal instauração, optando por uma solução meramente formal. ${ }^{48}$ No julgamento da

46 RTJ $145 / 775$ e $154 / 779$.

47 RTJ 164/506, ADIN(MC) 1.434-SP, rel. Min. Celso de Mello, in verbis: "A medida cautelar, em ação direta de inconstitucionalidade, reveste-se, ordinariamente, de eficácia ex nunc, operando, portanto, a partir do momento em que o Supremo Tribunal Federal a defere. Excepcionalmente, no entanto, a medida cautelar poderá projetar-se com eficácia ex tunc, com repercussāo sobre situações pretéritas. A excepcionalidade da eficácia ex tunc impõe que o Supremo Tribunal Federal expressamente a determine no acórdão concessivo da medida cautelar. A ausência de deterninação expressa importa em outorga de eficácia ex nunc à suspensão cautelar de aplicabilidade da norma estatal impugnada em ação direta. Concedida a medida cautelar (que se reveste de caráter temporário), a eficácia ex nunc (regra geral) tem seu início marcado pela publicação da ata da sessão de julgamento no Diário de Justiça da União, exceto em casos excepcionais a serem examinados pelo Presidente do Tribunal, de maneira a garantir a eficácia da decisão."

48 Reclamação (AgRg) n" 425-3/RJ, in JSTF, LEX, vol. 181, p. 171. Ver também, no mesmo sentido, RTJ 152/371 
Reclamação (AgRg) no 425-3/RJ. a Corte Suprema fixou seu entendimento sobre a matéria na forma das proposições abaixo:

a) a circunstância de a ação de inconstitucionalidade sustentar ofensa a norma da Carta estadual, que constitua repetição de norma da Constituição Federal, não é, em si, suficiente a autorizar, pela via da reclamação, interdite o STF o conhecimento e julgamento do litígio pelo Tribunal de Justiça local;

b) em se tratando de lei estadual, esta poderá ser simultaneamente impugnada perante o STF e a Corte local, hipótese em que a representação de inconstitucionalidade no âmbito estadual deverá ter seu curso suspenso até a decisão final do STF;

c) a decisão do STF vincula o Tribunal de Justiça local, restando prejudicada a representação de inconstitucionalidade simultaneamente ajuizada no âmbito estadual;

d) caso a representação de inconstitucionalidade ajuizada no âmbito estadual esteja baseada em outros fundamentos que não hajam sido apreciados pelo STF, a representação prosseguirá por tais fundamentos.

\section{III.2. Cabimento de recurso extraordinário e de suspensão de segurança}

O mesmo Supremo Tribunal Federal deixou assentado que, na hipótese acima, seria interponível recurso extraordinário da decisão da Corte local, caso esta "contrarie o sentido e o alcance da Constituição da República." 49 Em tal circunstância, excepcionalmente, a decisão proferida pelo Supremo Tribunal Federal no recurso extraordinário se sub-rogará nos mesmos efeitos erga omnes de que se revestia o acórdão prolatado pelo Tribunal de Justiça estadual.

O recurso extraordinário será cabível, em tese, com fincas nas alíneas "a" ou "c", do inciso III do art. 102 da Constituição Federal, conforme o caso.

Como corolário de tal entendimento, o Supremo Tribunal Federal vem igualmente admitindo a extensão do pedido de suspensão da execução de liminar, fundado no art. $4^{\circ}$ da Lei $n^{0} 8.437 / 92$, às medidas cautelares concedidas pelos Tribunais de Justiça em sede de controle abstrato.

Recentemente, aliás, o Presidente do Supremo Tribunal Federal, valendo-se de tal preceptivo, suspendeu a liminar que havia sido concedida pelo Tribunal de Justiça do Estado de Minas Gerais em representação de inconstitucionalidade na qual se questionava a validade de cláusula de contrato de refinanciamento de dívidas daquele Estado com a União Federal. ${ }^{50}$

49 RTJ $147 / 404$.

50 Petição n² 1.654-8-MG, rel. Min. Celso de Mello, DJU 18.02.99. 
A Emenda Constitucional $n^{\varrho}$ 03/93 introduziu a ação declaratória de constitucionalidade no direito brasileiro. Logo após a edição da Emenda, inúmeros juristas publicaram estudos sustentando a inconstitucionalidade da nova ação. ${ }^{51}$ O Supremo Tribunal Federal, no entanto, no julgamento da Ação Declaratória de Constitucionalidade $\mathrm{n}^{\mathrm{0}}$ 1-1 - DF, ao apreciar questão de ordem, rejeitou tal alegação de inconstitucionalidade. A decisão foi tomada por ampla maioria, ficando vencido, solitariamente, o eminente Ministro Marco Aurélio.

\section{IV.1. O efeito vinculante: diferença em relação à $A D I N$ ?}

$\mathrm{O}$ art. 102, § 2o, da Constituição, introduzido pela EC no 03/93, dispõe que as decisões definitivas de mérito proferidas pelo Supremo Tribunal Federal em ações declaratórias de constitucionalidade produzirão eficácia contra todos e efeito vinculante em relação aos demais órgãos do Poder Judiciário e ao Poder Executivo.

Pois bem. Diante da redação do dispositivo, qual seria o efeito da declaração da improcedência do pedido formulado em uma ação declaratória de constitucionalidade? A resposta é quase tautológica: o reconhecimento da inconstitucionalidade do ato normativo que foi objeto da ação, com eficácia vinculante e erga omnes. Com efeito, a norma constitucional alude a decisão definitiva de mérito, pouco importando se o juízo foi de procedência ou de improcedência.

Por razões de ordem lógica e de coerência sistêmica, o mesmo raciocínio deve ser aplicado às ações diretas de inconstitucionalidade. ${ }^{52}$ Isto é: em caso de improcedência do pedido formulado na ADIN, todos os demais órgãos do Poder Judiciário e o Poder Executivo ficam impedidos de negar aplicação à norma que teve a sua constitucionalidade proclamada pelo Supremo Tribunal Federal.

\section{IV.2. Requisito de admissibilidade: divergência jurisprudencial sobre a constitucionalidade do ato normativo}

O Supremo Tribunal Federal assentou o entendimento de que é necessária a demonstração da fundada incerteza sobre a constitucionalidade da lei ou ato normativo federal para ensejar o cabimento da ação declaratória de constitucionalidade. Tal incerteza deve ser comprovada pela juntada de sentenças e acórdãos dos Juízos e Tribunais, de modo a asseverar a controvérsia jurisprudencial quanto à legitimidade constitucional da norma que constitui o objeto da ação. ${ }^{53}$

51 V. Ação Declaratória de Constitucionalidade, Coord. Ives Gandra da Silva Martins e Gilmar Ferreira Mendes. Ed. Saraiva, 1994.

52 V., no mesmo sentido, Oswaldo Luiz Palu, Controle de Constitucionalidade - Conceitos, sistemas e efeitos. Ed. Revista dos Tribunais, 1999.

53 RTJ 157/371. 
IV.3. Cabimento de medida cautelar, inobstante a ausência de previsão constitucional expressa (poder geral de cautela)

O Supremo Tribunal Federal também já entendeu que é cabível a concessão de liminar, em ação declaratória de constitucionalidade, inobstante a inexistência de previsão constitucional expressa, fundando-se, para tanto, no poder geral de cautela reconhecido a todo Juiz ou Tribunal..$^{54}$

\section{IV.4. Efeitos da concessão da liminar}

No julgamento do pedido de medida cautelar na ação declaratória de constitucionalidade $n^{0}$ 4-6, cujo objeto era dispositivo da Lei $n^{0}$ 9.494/96 que proibiu, em determinadas hipóteses, a antecipação da tutela jurisdicional contra a Fazenda Pública, a Corte Suprema concede liminar, com efeitos ex nunc, para impedir a concessão de tutelas antecipadas dali em diante, bem como para sustar os efeitos futuros daquelas anteriormente concedidas.

\section{IV.5. Obrigatoriedade de contraditório?}

Embora se entenda que as ações de constitucionalidade fazem instaurar um processo objetivo, é inegável que, ao menos em relação à ação direta de inconstitucionalidade, o constituinte se preocupou em assegurar a existência do contraditório. Esta, precisamente, a função do Advogado-Geral da União, já estudada linhas atrás.

Não há, de fato, previsão semelhante para a ação declaratória de constitucionalidade. Nada obstante, em reverência ao princípio do contraditório, consagrado no inciso LV do art. $5^{\circ}$ da Constituição, seria conveniente que a lei ordinária criasse a oportunidade processual para a manifestação dos entes legitimados à propositura da ação direta de inconstitucionalidade, com vistas à impugnação do pedido declaratório de constitucionalidade.

\section{CONCLUSÃO}

O controle abstrato da constitucionalidade experimentou um notável desenvolvimento no Brasil, desde a promulgação da Constituição de 1988. Neste período, o Supremo Tribunal Federal ganhou visibilidade como "árbitro" dos conflitos horizontais e verticais entre Poderes, contribuindo efetivamente para o equilíbrio institucional e federativo, a defesa das minorias e o fortalecimento da democracia. $\mathrm{O}$ desenvolvimento do sentimento constitucional - viga mestra da cidadania - está

54 ADC n² 4-6, rel. Min. Sydney Sanches, DJU de 13.02.1998. 
umbilicalmente ligado ao exercício da jurisdição constitucional, momento crucial em que se realizam, ou se frustram, os valores consagrados na Constituição.

À técnica processual incumbe contribuir, orientada sempre pelo princípio da instrumentalidade das formas, para que a jurisdição constitucional cumpra a sua missão.

\section{BIBLIOGRAFIA}

BARROSO, Luís Roberto. Dez Anos da Constituição de 1988 (Foi bom pra você também?) in Revista de Direito Administrativo n 214, 1998.

BITTENCOURT, Carlos Alberto Lucio. O controle jurisdicional da constitucionalidade das leis, 1968.

CAPPELLETTI, Mauro. O Controle Judicial de Constitucionalidade das Leis no Direito Comparado, 1992.

LOURENÇO, Rodrigo Lopes. Controle da Constitucionalidade à Luz da Jurisprudência do SUPREMO TRIBUNAL FEDERAL, 1998.

MENDES, Gilmar Ferreira. A Evolução do Direito Constitucional Brasileiro e o Controle de Constitucionalidade da Lei in Direitos Fundamentais e Controle de Constitucionalidade, 1998.

MENDES, Gilmar Ferreira. Controle de Constitucionalidade - Aspectos Jurídicos e Políticos, 1990.

MENDES, Gilmar Ferreira. Jurisdição Constitucional, 1996.

PALU, Oswaldo Luiz. Controle de Constitucionalidade - Conceitos, sistemas e efeitos. Ed. Revista dos Tribunais, 1999.

SARMENTO, Daniel. Eficácia Temporal do Controle de Constitucionalidade (O Princípio da Proporcionalidade e a Ponderação de Interesses) das Leis, in Revista de Direito Administrativo no 212, 1998. 